\title{
Review of Antibiotic Resistance in the Indian Ocean Commission: A Human and Animal Health Issue
}

\begin{abstract}
Noellie Gay ${ }^{1 *}$, Olivier Belmonte ${ }^{2}$, Jean-Marc Collard ${ }^{3}$, Mohamed Halifa, Mohammad lqbal Issack ${ }^{5}$, Saindou Mindjae ${ }^{6}$, Philippe Palmyre7, Abdul Aziz Ibrahim ${ }^{7}$, Harena Rasamoelina ${ }^{8}$, Loïc Flachet ${ }^{8}$, Laurent Filleul ${ }^{9}$ and Eric Cardinale ${ }^{1,8}$

${ }^{1}$ Animals, Health, Territories, Risks and Ecosystems Unit, Department of Animal Health, French Agricultural Research Center for International Development (CIRAD), Montpellier, France, ${ }^{2}$ Bacteriology Laboratory, Félix Guyon Hospital, Saint-Denis, Reunion, ${ }^{3}$ Experimental Bacteriology Unit, Pasteur Institute of Madagascar, Antananarivo, Madagascar, ${ }^{4}$ El Maroof Hospital, Moroni, Comoros, ${ }^{5}$ Central Health Laboratory, Victoria Hospital, Candos, Mauritius, ${ }^{6}$ General Direction of Health, Moroni, Comoros, ${ }^{7}$ Victoria Hospital, Victoria, Seychelles, ${ }^{8}$ Health Monitoring Unit, Indian Ocean Commission, Port-Louis, Mauritius, ${ }^{9}$ Regional Unit of Indian Ocean, Santé Publique France, Saint-Denis, Reunion
\end{abstract}

OPEN ACCESS

Edited by:

Ahmed Mohamed,

North Carolina State

University, United States

Reviewed by: Malathi Raghavan,

Purdue University,

United States

Xiangzhu Zhu,

Vanderbilt University,

United States

${ }^{*}$ Correspondence:

Noellie Gay

noellie.gay@cirad.fr

Specialty section: This article was submitted to

Epidemiology,

a section of the journal

Frontiers in Public Health

Received: 07 April 2017

Accepted: 21 June 2017

Published: 06 July 2017

Citation:

Gay N, Belmonte O, Collard J-M, Halifa M, Issack MI, Mindjae S,

Palmyre $P$, Ibrahim $A A$,

Rasamoelina H, Flachet L, Filleul $L$ and Cardinale E (2017) Review of

Antibiotic Resistance in the Indian

Ocean Commission: A Human and Animal Health Issue.

Front. Public Health 5:162. doi: 10.3389/fpubh.2017.00162
Antimicrobial resistance (AMR) is a major threat to human, animal health, and environment worldwide. For human, transmission occurred through a variety of routes both in health-care settings and community. In animals, AMR was reported in livestock, pets, and wildlife; transmission of AMR can be zoonotic with the probably most important route being foodborne transmission. The Indian Ocean Commission (IOC), composed of Comoros, Madagascar, Mauritius, Reunion (France), and Seychelles recognized the surveillance of AMR in both animal and human as a main public health priority for the region. Mayotte, French overseas territory, located in Comoros archipelago, was also included in this review. This review summarized our best epidemiological knowledge regarding AMR in Indian Ocean. We documented the prevalence, and phenotypic and genotypic profiles of prone to resistance Gram-positive and Gram-negative bacteria both in animals and humans. Our review clearly pointed out extended-spectrum $\beta$-lactamase and carbapenemase-producing Enterobacteriaceae as main human and animal health issue in IOC. However, publications on AMR are scarce, particularly in Comoros, Mayotte, and Seychelles. Thus, research and surveillance priorities were recommended (i) estimating the volume of antimicrobial drugs used in livestock and human medicine in the different territories [mainly third generation cephalosporin (3GC)]; (ii) developing a "One Health" surveillance approach with epidemiological indicators as zoonotic foodborne pathogen (i.e., couple Escherichia coli resistance to 3GC/carbapenems); (iii) screening travelers with a history of hospitalization and consumption of antibiotic drug returning from at risk areas (e.g., mcr-1 transmission with China or hajj pilgrims) allowing an early warning detection of the emergence for quick control measures implementation in IOC.

\section{Keywords: Indian Ocean, epidemiology, antimicrobial resistance, One Health, prevalence, surveillance, zoonosis}

\section{INTRODUCTION}

Increasing global antimicrobial resistance (AMR) is a major threat to human and animal endangering decades of improvements in health-care outcomes. It endangers modern human and veterinary medicine and undermines food safety (1).

In humans, the global burden of AMR is longer duration of illness, higher lethality, increasing costs of treatment, and inability to cure infected patient (2). In animals, antibiotic drugs use in 
terrestrial and aquatic animals maintains food safety, animal welfare, and protect livelihoods (3).

Transmission of AMR to human can be zoonotic taking place through a variety of routes where the foodborne route is probably the most important (4). Direct transmission also occurs for specific bacteria species [e.g., methicillin-resistant Staphylococcus aureus (MRSA)].

The Indian Ocean Commission (IOC) is composed of five countries: Comoros, Madagascar, Mauritius, Reunion (France), and Seychelles. Mayotte, French overseas territory located in Comoros archipelago, was also included in the study. In 2015, the IOC identified AMR surveillance in both animal and human as a main priority for territories (5). However, AMR burden is not well evaluated but epidemiological trends in IOC should be identified.

Our systematic review objective was summarizing epidemiological knowledge and trends of AMR in prone-to-multidrug resistance bacteria species (6), and fecal-oral and foodborne bacteria in human and animals in IOC. We documented the prevalence, and phenotypic and genotypic profiles of resistance of the selected bacteria in (i) Gram-positive and (ii) Gram-negative bacteria.

\section{MATERIALS AND METHODS}

The study performed from January to March 2017 included articles and conference abstracts published from 1990 to December 2016. Bacteria species included in the different searches were those prone to develop multidrug resistance as defined by Magiorakos et al. (6) (i.e., S. aureus, Enterococcus spp., Pseudomonas aeruginosa, Acinetobacter spp., and the genus Enterobacteriaceae), and fecal-oral and foodborne bacterial species (Salmonella spp., Campylobacter spp., and Shigella spp.). We used available articles obtained through match searches using Google Scholar, ${ }^{1}$ PubMed, ${ }^{2}$ and Web of Knowledge. ${ }^{3}$ Relevant information was obtained for phenotypic and genotypic profiles of resistance in selected bacteria using its name combined with related terms (resistance, antimicrobial, antibiotic, Comoros, Seychelles, Reunion Island, Madagascar, Mayotte, Indian Ocean, epidemiology). Included publications were those documenting the prevalence, and phenotypic and genotypic profiles of resistances of selected bacteria; others were excluded.

\section{RESULTS AND DISCUSSION}

A total of 42 articles were considered relevant for the review.

\section{Gram-Positive Bacteria Staphylococcus aureus}

Staphylococcus aureus is one of the most common causes of nosocomial and community infections (7). Since 1960s, MRSA was isolated (8) and became a major nosocomial pathogen (9).

${ }^{1}$ http://scholar.google.com.

${ }^{2}$ https://www.ncbi.nlm.nih.gov/pubmed.

${ }^{3}$ http://apps.webofknowledge.com/.
In Madagascar, MRSA was increasing from 2001 to 2014 as observed in Table 1 with rising rate of resistance to oxacillin and cefoxitin. MRSA nasal carriage in community was observed with a prevalence of $14.8 \%$ in $2011(10,11)$. Overall resistances were higher for widely available drugs (12). Moreover, $9.0 \%$ of veterinary students were asymptomatic MRSA carriers (11). Increasing rate of resistance to gentamicin (42.9\%) and vancomycin (7.1\%) was observed in MRSA isolates (11). Nonetheless, vancomycin and tigecycline are the last drugs demonstrating therapeutic efficacy for MRSA and are compromised by the reduced susceptibility in $S$. aureus (13). Phenotypic resistance observed in Madagascar was of concern (11), confirmation by an antimicrobial reference laboratory for genotyping should be considered.

In Mauritius, in May 2010, among all S. aureus isolated in hospitalized patients' infections, $37.8 \%$ were MRSA (16) and 39\% were MRSA in July 2014 (18). All S. aureus tested were susceptible to vancomycin $(16,18)$.

In Reunion, MRSA increased from $16.0 \%$ in 1997 to $23.0 \%$ in 2000 and decreased to less than $15.0 \%$ in 2006/2007 (14). $S$. aureus rate of resistance to all antibiotic drugs decreased from 1997 to 2007, with the exception of the fusidic acid (16.0\% in 2007). Since 1998, S. aureus susceptibility profile changed tending to be more resistant to aminoglycosides and quinolones (14).

In the other territories, literature remains absent and no publication was found regarding prevalence and antibiotic resistance profiles of $S$. aureus in humans, livestock, and pets.

Methicillin-resistant Staphylococcus aureus epidemiological trends should be better addressed in Comoros, Mayotte, Reunion, and Seychelles. Rates of resistances for widely available oral agents observed in Madagascar could point out a drug overuse in this territory as well as in Mauritius.

Burden of MRSA in livestock and pets should be addressed particularly as they can directly contaminate veterinary, breeders, or other animals (19).

\section{Enterococcus spp.}

Enterococcus spp. are opportunistic bacteria often involved in nosocomial infections, mainly urinary tract infections, endocarditis, wounds, and bacteremia (20). Discovered by the end of the 1980s (21), vancomycin-resistant enterococci (VRE) represent a major problem in health-care settings worldwide.

In Madagascar, in 2006-2008, rate of resistance to vancomycin in Enterococcus spp. was 3.3\% and was high for lincomycin (90.0\%) (15). In 2011-2013, one E. faecalis resistant to vancomycin (5.6\%) was isolated during an uropathogenic survey (17).

In Mauritius, in May 2010 and July 2014, all Enterococcus spp. isolated in hospitalized patients were susceptible to vancomycin $(16,18)$.

In Reunion, Picot et al. (22) did not detect any VRE in 2005. In other territories, no publication was found for both humans and animals.

Thus, epidemiological situation of VRE is not clear in IOC but does not seem being a main issue both in animals and humans. Identifying drug uses in livestock remains necessary as glycopeptide (e.g., avoparcin) use in livestock was correlated with VRE incidence in human populations (23). 


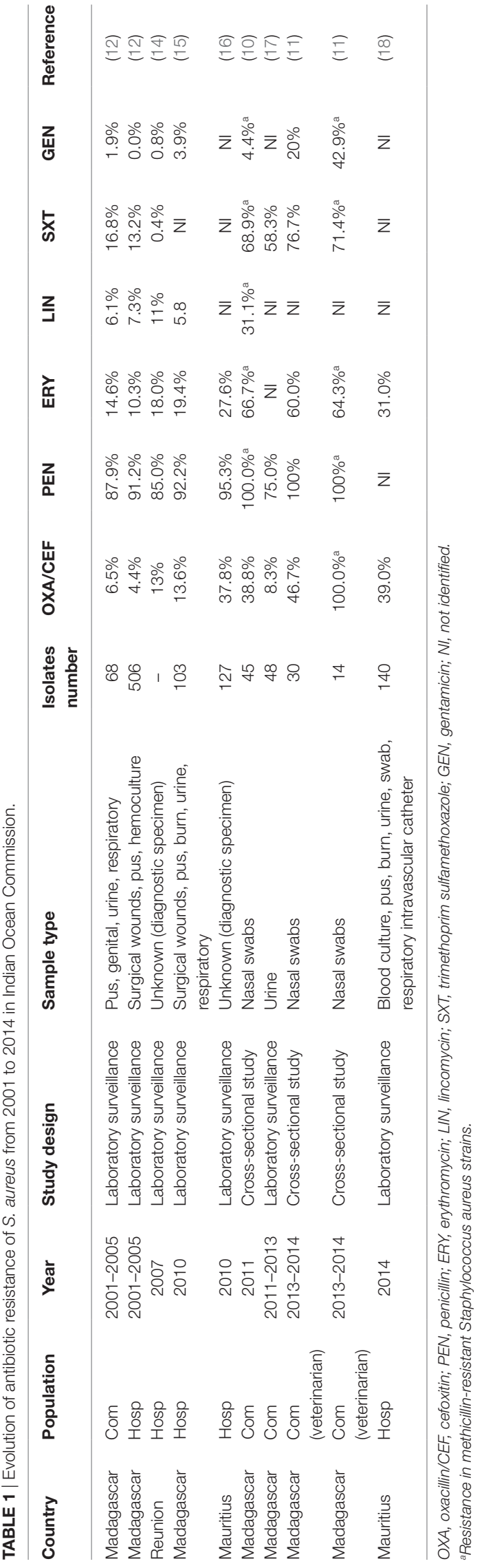

\section{Gram-Negative Bacteria Pseudomonas aeruginosa}

Pseudomonas aeruginosa is an opportunistic pathogen causing nosocomial infections (24). Some strains have been found to be resistant to nearly all antibiotics (25).

In Madagascar, in 2006-2008, P. aeruginosa isolates showed a moderate resistance to penicillin (piperacillin $12.8 \%$ and ticarcillin $31.9 \%$ ) but were susceptible to ceftazidime and imipenem (15).

In Mauritius, in May 2010, P. aeruginosa isolated in hospitalized patients showed high rate of resistance to antibiotic tested with $51.5 \%$ to aminoglycosides (52\% gentamicin and $51 \%$ amikacin), $47 \%$ for ceftazidime, $73 \%$ for ciprofloxacin, and $40 \%$ for meropenem (16). In July 2014, a similar survey pointed a decrease of all resistance tested ( $42 \%$ for gentamicin, $29 \%$ for amikacin, 30\% for ceftazidime, $47 \%$ for ciprofloxacin, and $27 \%$ for meropenem) (18).

In Reunion, rates of resistance to imipenem increased from 1997 to 2005 (5.9-6.1\%) (22). Outbreaks of P. aeruginosa were reported in a neonatal care unit $(26,27)$, but susceptibility testing of strain was not performed. In Reunion, between 2010 and 2012, OXA-221 was identified in P. aeruginosa associated with $\beta$-lactamases and carbapenemase production (28). The extended-spectrum $\beta$-lactamase OXA-145 was described in 2011 in $P$. aeruginosa and conferred resistance to third generation cephalosporin (3GC) and monolactams (29).

Trends regarding $P$. aeruginosa in IOC are not clear, but acquisition of new gene of resistance to $\beta$-lactams is of concern. Rate of resistance to carbapenems identified in Mauritius are high even if decreasing. Identifying its burden in nosocomial infection is needed as well as aminoglycoside resistance. Recommended treatment for pseudomonas infection usually includes $\beta$-lactams and aminoglycosides.

\section{Acinetobacter spp.}

Acinetobacter baumannii is a troublesome pathogen for healthcare institutions, and its ability to acquire resistance determinants is making it threatening the current antibiotic era (30).

In Madagascar, in 2006-2008, a prevalence of A. baumannii of $8.8 \%$ was identified in infections diagnosed at hospital, the resistance to ceftazidime (62.0\%) and imipenem was high (45.7\%) (15). Among strains collected between 2006 and 2009, 92.5\% were resistant to imipenem and $94.3 \%$ to ceftazidime (31). No resistance to carbapenems was reported among ten uropathogenic isolates in community (2011-2013) (17), but this restricted sample could not reflect the epidemiological situation. The dissemination of multidrug-resistant OXA-23-producing A. baumannii in hospitals of Antananarivo (31) could emphasize issues regarding failures of infection control in hospitals (15).

In Mauritius, in May 2010, Acinetobacter spp. isolated in hospitalized patients showed high rate of resistance to antibiotic tested with $86 \%$ for gentamicin and 50\% for amikacin (both aminoglycosides), $95 \%$ for cefotaxime, $85 \%$ for ciprofloxacin, and $68 \%$ for meropenem (16). In July 2014, a similar survey pointed a decreasing rate of resistance for gentamicin, cefotaxime, and ciprofloxacin (respectively 79, 94, and 82\%) and increasing for amikacin (58\%) and meropenem (74\%) (18). 
In Reunion, from 1997 to 2005, A. baumannii rate of resistance decreased to all antibiotic tested [e.g., ceftazidime (74.3-68.1\%), imipenem (12.9-8.3\%), and ciprofloxacin (72.9-59.7\%)] (22). In 2006, an outbreak of multiresistant $A$. baumannii phenotype 5 occurred at the hospital, strains were resistant to all $\beta$-lactams (32). A wide variety of $A$. baumannii sequence types was identified at the hospital and could be related to communityacquired infections; one isolate carrying the $b l a_{{\mathrm{OXA}-23^{-}}^{-}}$gene was identified (33).

In Comoros, the bla $a_{\text {OXA-23- }}$ gene in A. baumannii was identified in 2011 (34).

Pets can be reservoir of $A$. baumannii (35). In Reunion, the prevalence in pets was $8.5 \%$ but no isolates were resistant to carbapenems (33). In cattle, the first case of OXA-24- producing A. baumannii was recently identified (36).

Resistance to carbapenems in A. baumannii was observed in Comoros, Madagascar, Reunion, and Mauritius. It is of concern for IOC as A. baumannii have an affinity with vulnerable patients (37). Producing-carbapenemase A. baumannii, with the dissemination of OXA-23 enzymes, should be thoroughly monitored, keeping in mind the possible clonal spread of multiresistant strains in hospital, community, and pets.

\section{Enterobacteriaceae}

$\beta$-Lactamase production are the primary cause of resistance among members of the family Enterobacteriaceae. In recent years, $\beta$-lactamases have extensively diversified in response to clinical use of $\beta$-Lactams (38).

\section{Extended-Spectrum $\beta$-Lactamase-Producing Enterobacteriaceae (ESBLE)}

Extended-spectrum $\beta$-lactamase-producing Enterobacteriaceae confer resistance to $\beta$-lactam antibiotics except cephamycins and carbapenems and are inhibited by clavulanic acid (39).

Extended-spectrum $\beta$-lactamase-producing Enterobacteriaceae was first isolated in Madagascar between 2004 and 2006 in urinary tract infections (40) as observed in Table 2. High fecal carriage of ESBLE was identified in both hospital and community with prevalence of $21.3 \%$ in two hospitals from 2006 to 2008 (15), $21.2 \%$ in a pediatric hospital in 2008 (41), and $10.1 \%$ in community in 2009 (42). Between 2013 and 2014, $18.5 \%$ of rectal colonization was estimated among pregnant women at delivery (43). Another study (2015) pointed out $7.1 \%$ of Enterobacteriaceae nasal carriage resistance to $3 \mathrm{GC}$ in patients at admission (44). A study conducted from 2012 to 2013 pointed out the burden of ESBLE in early neonatal infection (12.9\%); infections were treated with expanded spectrum cephalosporins due to the lack of carbapenems and resulted in a high lethality (45\%) (45). In Madagascar, ESBLE mostly belong to the CTX-M-15 type $(45,46)$, widely distributed worldwide (47).

In Mauritius, in 2005, rate of resistance to 3GC in Enterobacteriaceae from urine of patients with presumed communityacquired infection was about $9.0 \%$ for cefotaxime and $14.7 \%$ for cefixime (Table 2). Isolates also showed high rates of resistance to fluoroquinolones (26.4\% to ciprofloxacin) (48). Between 2010 and 2014, an increase of resistance in Enterobacteriaceae isolated in hospitalized patients was observed (46.7-50.7\% for cefotaxime and $39.2-56.1 \%$ for ciprofloxacin) $(16,18)$.

In Reunion, prevalence of ESBLE was increasing at hospital with $2.0 \%$ in 1997 and 5.8\% in 2007 (32). Broad spectrum antibiotics use in hospitals was likely correlated with this evolution (32). In 2013, main ESBLE involved in infections were Klebsiella pneumoniae (38.0\%), Escherichia coli (37.0\%), and Enterobacter cloacae $(24.0 \%)$ with $75.0 \%$ of the CTX-M-15 type (50).

A prevalence of $14.5 \%$ ESBLE was estimated among dogs and cats from veterinary clinics of Reunion Island (51).

In livestock from Comoros, Madagascar, Mauritius, and Mayotte, overall $22.7 \%$ of livestock sampled were ESBLE carriers. The highest prevalence was observed among pigs (42.0\%) and poultry $(26 \%)$; main contaminated farms were located in Madagascar (40.5\%), Mayotte (26.9\%) followed by Mauritius (13.5\%) and Comoros (6.7\%) (52).

No publication was found for Seychelles, but prevalence of ESBLE (mainly represented by E. coli, K. pneumoniae, and E. cloacae) in IOC seems increasing both in humans and animals. Broad spectrum antibiotics overuse is likely correlated with this evolution (32).

\section{Carbapenemase-Producing Enterobacteriaceae (CPE)}

In Madagascar, first CPE was reported in a community survey of uropathogens implemented in 2011-2013 (17). Imipenem rate of resistance was $40.0 \%$ for K. pneumoniae, $15.0 \%$ for E. cloacae, and $2.3 \%$ for E. coli (17). The reduced sample size for this study could not reflect global resistances patterns.

In Mauritius, rate of resistance to meropenem in Enterobacteriaceae increased from $0.51 \%$ in 2010 to $5.32 \%$ in 2014 among hospitalized patients $(16,18)$.

In Reunion, in 2007, resistance to imipenem in Enterobactericeae was low (1 to 2 cases by year) (14).

First detection of New Delhi metallo- $\beta$-lactamase-1 (NDM-1) gene in K. pneumoniae in IOC occurred in a Mauritius patient in 2009 (53), in 2011 in Reunion (54), and in 2013-2014 in Madagascar (43).

In Mayotte, an outbreak of CPE involving E. cloacae of IMI-1 type occurred at the hospital (55). First investigations tend to highlight a community source of contamination but further investigations should confirm it (55).

In animal, no publication was found regarding CPE.

Carbapenemase-producing Enterobacteriaceae are endangering the ability to cure infectious diseases. NDM-1 fast propagation in IOC is pointing the need of AMR surveillance and alert system. Mauritius seems particularly affected by $\mathrm{CPE}$; their spread could constitute an issue for other territories as few therapeutic alternatives are available to treat infected patients.

\section{Foodborne and Fecal-Oral Origin Enterobacteriaceae}

Non-Typhoidal Salmonella spp. Salmonella is a major foodborne pathogen found worldwide. Most human salmonellosis is associated with eating contaminated raw or undercooked chicken, eggs, pork, and contaminated water.

In Madagascar, in 2008-2009, Salmonella spp. rate of resistance in community children was low for $3 \mathrm{GC}$ (1.2\% for ceftazidime 
TABLE 2 | Evolution of antibiotic resistance of Enterobacteriaceae from 2004 to 2013 in Indian Ocean Commission.

\begin{tabular}{|c|c|c|c|c|c|c|c|c|c|c|c|c|c|c|c|}
\hline $\begin{array}{l}\text { Country/ } \\
\text { year }\end{array}$ & Population & $\begin{array}{l}\text { Study } \\
\text { design }\end{array}$ & Sample type & $\begin{array}{l}\text { Isolates } \\
\text { number }\end{array}$ & $\begin{array}{c}\text { ESBL } \\
\text { carriers/ } \\
\text { individuals } \\
\text { tested }\end{array}$ & $\begin{array}{c}\text { ESBLE/ } \\
\text { Enterobacteriaceae } \\
\text { tested }\end{array}$ & AMX & AMC & CAZ/CEF & GEN & NAL & CIP & SXT & Bacterial species & Reference \\
\hline $\begin{array}{l}\text { Madagascar } \\
\text { 2004-2006 }\end{array}$ & Com & $\begin{array}{l}\text { Laboratory } \\
\text { surveillance }\end{array}$ & Urine & 775 & $\mathrm{NI}$ & $3.8 \%$ & $76.4 \%$ & $15.6 \%$ & $4.0 \% /-$ & $9.2 \%$ & $24.5 \%$ & $15.4 \%$ & $64.8 \%$ & $\begin{array}{l}\text { Escherichia coli, Klebsiella } \\
\text { pneumoniae, Proteus } \\
\text { spp., Enterobacter spp., } \\
\text { Citrobacter spp. }\end{array}$ & (40) \\
\hline $\begin{array}{l}\text { Mauritius } \\
2005\end{array}$ & Com & $\begin{array}{l}\text { Laboratory } \\
\text { surveillance }\end{array}$ & Urine & 224 & $\mathrm{NI}$ & $12.9 \%$ & $\mathrm{NI}$ & $1.60 \%$ & $-/ 9.0 \%$ & $9.9 \%$ & $34.0 \%$ & $26.4 \%$ & $49.5 \%$ & $\begin{array}{l}\text { E. coli, Klebsiella spp., } \\
\text { Proteus spp. }\end{array}$ & (48) \\
\hline $\begin{array}{l}\text { Reunion } \\
\text { 2006-2007 }\end{array}$ & Hosp & $\begin{array}{l}\text { Laboratory } \\
\text { surveillance }\end{array}$ & $\begin{array}{l}\text { Unknown } \\
\text { (diagnostic } \\
\text { specimen) }\end{array}$ & $240^{\mathrm{a}}$ & $\mathrm{NI}$ & $5.8 \%$ & $\mathrm{NI}$ & $\mathrm{NI}$ & $\mathrm{NI}$ & $67.0 \%$ & $\mathrm{NI}$ & $74.0 \%$ & $75.0 \%$ & $\begin{array}{l}\text { E. coli, Enterobacter } \\
\text { cloacae, K. pneumoniae }\end{array}$ & (32) \\
\hline $\begin{array}{l}\text { Madagascar } \\
\text { 2006-2008 }\end{array}$ & Hosp & $\begin{array}{l}\text { Laboratory } \\
\text { surveillance }\end{array}$ & $\begin{array}{l}\text { Surgical } \\
\text { wounds, pus, } \\
\text { burn, urine, } \\
\text { respiratory }\end{array}$ & 249 & $\mathrm{NI}$ & $21.3 \%$ & $91.0 \%$ & $69.0 \%$ & $26.0 \% / 26.0 \%$ & $31.0 \%$ & $52.0 \%$ & $41.0 \%$ & $71.0 \%$ & $\begin{array}{l}\text { E. coli, K. pneumoniae, } \\
\text { Proteus spp., } \\
\text { Enterobacter spp., } \\
\text { Citrobacter spp. }\end{array}$ & (15) \\
\hline $\begin{array}{l}\text { Madagascar } \\
2008\end{array}$ & Hosp & $\begin{array}{l}\text { Cohort } \\
\text { study }\end{array}$ & Stool & $30^{\mathrm{a}}$ & $57.10 \%$ & $\mathrm{NI}$ & $100.0 \%$ & $100.0 \%$ & $86.2 \%$ & $91.4 \%$ & $62.0 \%$ & $50.0 \%$ & $96.5 \%$ & E. coli, K. pneumoniae & (41) \\
\hline $\begin{array}{l}\text { Madagascar } \\
2008\end{array}$ & Com & $\begin{array}{l}\text { Cohort } \\
\text { study }\end{array}$ & Stool & $58^{a}$ & $22.10 \%$ & $\mathrm{NI}$ & $100.0 \%$ & $100.0 \%$ & $90.0 \%$ & $76.7 \%$ & $63.3 \%$ & $46.7 \%$ & $93.3 \%$ & E. coli, K. pneumoniae & (41) \\
\hline $\begin{array}{l}\text { Madagascar } \\
\text { 2008-2009 }\end{array}$ & Com & $\begin{array}{l}\text { Cross- } \\
\text { sectional } \\
\text { study }\end{array}$ & Stool & 195 & $\mathrm{NI}$ & $3.1 \%$ & $82.1 \%$ & $1.0 \%$ & $1.5 \% / 3.1 \%$ & $1.0 \%$ & $10.8 \%$ & $3.1 \%$ & $84.6 \%$ & E. coli & (49) \\
\hline $\begin{array}{l}\text { Madagascar } \\
2009\end{array}$ & Com & $\begin{array}{l}\text { Cross- } \\
\text { sectional } \\
\text { study }\end{array}$ & Stool & $53^{a}$ & $\mathrm{NI}$ & $\mathrm{NI}$ & $100.0 \%$ & $98.0 \%$ & $\mathrm{NI}$ & $\mathrm{NI}$ & $68.6 \%$ & $60.8 \%$ & $90.2 \%$ & $\begin{array}{l}\text { E. coli, K. pneumoniae, } \\
\text { Enterobacter spp., } \\
\text { Citrobacter spp. }\end{array}$ & (42) \\
\hline $\begin{array}{l}\text { Mauritius } \\
2010\end{array}$ & Hosp & $\begin{array}{l}\text { Laboratory } \\
\text { surveillance }\end{array}$ & $\begin{array}{l}\text { Unknown } \\
\text { (diagnostic } \\
\text { specimen) }\end{array}$ & 195 & $\mathrm{NI}$ & $\mathrm{NI}$ & $\mathrm{NI}$ & $\mathrm{NI}$ & $46.7 \%$ & $50.6 \%$ & $\mathrm{NI}$ & $39.2 \%$ & $\mathrm{NI}$ & E. coli, K. pneumoniae & (16) \\
\hline $\begin{array}{l}\text { Madagascar } \\
\text { 2011-2013 }\end{array}$ & Com & $\begin{array}{l}\text { Laboratory } \\
\text { surveillance }\end{array}$ & Urine & $224^{\mathrm{a}}$ & $\mathrm{NI}$ & $33.0 \%$ & $80.8 \%$ & $58.0 \%$ & $30.4 \%-30.4 \%$ & $\mathrm{NI}$ & $\mathrm{NI}$ & $\mathrm{NI}$ & $69.2 \%$ & $\begin{array}{l}\text { E. coli, Citrobacter spp., } \\
\text { K. pneumoniae, Proteus } \\
\text { spp., Serratia spp. }\end{array}$ & (17) \\
\hline $\begin{array}{l}\text { Madagascar } \\
\text { 2013-2014 }\end{array}$ & $\begin{array}{l}\text { Pregnant } \\
\text { women }\end{array}$ & $\begin{array}{l}\text { Cohort } \\
\text { study }\end{array}$ & Stool & $66^{a}$ & $18.5 \%$ & $\mathrm{NI}$ & $\mathrm{NI}$ & $\mathrm{NI}$ & $\mathrm{NI}$ & $\mathrm{NI}$ & $\mathrm{NI}$ & $36.0 \%$ & $\mathrm{NI}$ & $\begin{array}{l}\text { E. coli, Citrobacter } \\
\text { freundii, K pneumoniae, } \\
\text { Enterobacter cloacae, } \\
\text { Morganella morganii }\end{array}$ & (43) \\
\hline $\begin{array}{l}\text { Mauritius } \\
2014\end{array}$ & Hosp & $\begin{array}{l}\text { Laboratory } \\
\text { surveillance }\end{array}$ & $\begin{array}{l}\text { Blood culture, } \\
\text { pus, burn, } \\
\text { urine, swab, } \\
\text { respiratory } \\
\text { intravascular } \\
\text { catheter }\end{array}$ & 301 & $\mathrm{NI}$ & $\mathrm{NI}$ & $\mathrm{NI}$ & $\mathrm{NI}$ & $50.7 \%$ & $33.2 \%$ & $\mathrm{NI}$ & $56.1 \%$ & $\mathrm{NI}$ & E. coli, K. pneumoniae & (18) \\
\hline
\end{tabular}

AMX, amoxicilin; AMC, amoxicillin + claviculanic acid; CAZ, ceftazidime; SXT, trimethoprim sulfamethoxazole; GEN, gentamicin; CIP, ciprofloxacin; NAL, nalidixic acid; CEF, cefotaxim; NI, not identified; ESBLE, Extended-Spectrum $\beta$-Lactamase-Producing Enterobacteriaceae.

${ }^{a} E S B L$ isolates only. 
and cefotaxime), absent for quinolones, and moderated for ampicillin (35.7\%) and ticarcillin (35.7\%) (49).

In Mauritius, in 2009, Salmonella enterica serovar Enteritidis was isolated in humans without resistance identified for all antibiotic tested; transmission by chicken consumption was suspected (56). In 2014, Salmonella spp. isolated in stools of patients with gastroenteritis were all sensitive to ampicillin and ciprofloxacin and presented low resistance to trimethoprim-sulfamethoxazole (2\%) and nalidixic acid (1\%) (57).

In Reunion, between 2007 and 2009, rates of resistance among Salmonella spp. isolated in broiler chicken flocks were of $38.3 \%$ to streptomycin, $31.8 \%$ to tetracycline, and $16.8 \%$ to ampicillin (58), but no resistance to $3 \mathrm{GC}$ was identified. S. Hadar displayed reduced susceptibility to fluoroquinolones $(80.8 \%$ to enrofloxacin) (58).

In Comoros, no resistance in Salmonella spp. was identified between 1987 and 1988 (59).

Publications regarding AMR among Salmonella spp. are scarce in IOC. Resistances to quinolones in Salmonella spp. seems appearing in Reunion, probably do to its overuse, but not in Mauritius.

Campylobacter spp. Campylobacter spp. can cause both gastroenteritis and extra-intestinal disease. C. jejuni and C. coli are the most often isolated from patients with diarrhea as confirmed in Madagascar in 2010-2012 (70.1 and 23.6\%, respectively) (60). Main infection source in humans is undercooked chicken, raw or unpasteurized milk, and cross-contamination from the environment (61).

In Madagascar, rate of resistance in Campylobacter spp. was moderate in community children in 2008-2009, with overall resistance of $24.8 \%$ for amoxicillin, $2.2 \%$ for ciprofloxacin, $1.8 \%$ for erythromycin, and $1.1 \%$ for tetracycline (49). Rate of resistance was higher for C. coli (49).

In animals, Campylobacter spp. collected in 2005-2006 from chicken neck skin in Madagascar presented 35.8\% of resistance to ampicillin, $18.3 \%$ to erythromycin, $5.5 \%$ to ciprofloxacin, and $3.7 \%$ to nalidixic acid (62).

In Mauritius, in 2014, Campylobacter spp. isolated in gastroenteritis cases presented high resistance to quinolones with $51 \%$ of resistance to ciprofloxacin and $4 \%$ to erythromycin (57). High quinolone resistance in Campylobacter spp. is probably due to antibiotic overuse in veterinary medicine (57).

Publications regarding AMR among Campylobacter spp. are scarce in IOC particularly in animals. Resistance to quinolones in Mauritius could be due to its overuse in poultry industry (57).

Shigella spp. Shigella spp. is responsible for dysentery predominating in developing countries (63).

In Madagascar, in 1988-1989, resistances in Shigella dysenteriae started being observed (64). In 2008-2009, rate of resistance in community children were high for widely used drugs (e.g., $79.9 \%$ for trimethoprim-sulfamethoxazole, $62.8 \%$ for amoxicillin, $62.2 \%$ for ticarcillin) but no resistance for ciprofloxacin was reported (49).

In Comoros, Shigella spp. isolated between 1987 and 1988 did not exhibit significant resistances (59).
Few up-to-date publications regarding AMR in Shigella spp. were found.

\section{PERSPECTIVES}

One main challenge regarding this review was the data collection and comparison of AMR patterns between territories in the diversity of study designs (diagnosis isolates vs. systematic detection), antibiogram panels, over different periods of time and targeting various bacteria species. Thus, results should be interpreted with caution but this attempt of review was not performed before and confirmed that AMR is threatening IOC. Main issue identified for IOC was ESBL and CPE which is in agreement with their increase worldwide over the past decade (65).

Literature was limited in Comoros, Mayotte, and Seychelles confirming needs to develop AMR surveillance and research in these territories and scarce for bacterial species: Enterococcus spp., P. aeruginosa, Salmonella spp., Campylobacter spp., and Shigella spp.

In IOC, the SEGA-One Health network was created in 2009 with the objective of monitoring outbreak-prone infections (66). It aims to develop a surveillance of AMR in human and animals but disparity of resources between territories and between animal and human health could be a brake in the establishment of such a system.

Thus, priorities should be established:

(i) A direct relationship between antibiotic consumption, emergence, and dissemination of AMR was demonstrated (67). Estimating the volume of antimicrobial drugs used, types, and access (e.g., over-the-counter) is an essential step for IOC. The overuse of 3GC could have driven to selection pressures on bacterial community in both animals and humans observed (i.e., ESBLE and CPE in hospitals with carbapenems use). Drugs monitoring could help predicting risks of emergence in territories (68). Research on drug uses and habits in community, by practitioners, and in livestock should be explored to adapt control measures.

(ii) Integrated AMR One Health approach including human, animal, and environment in both surveillance and research is clearly needed (e.g., MRSA in veterinarians, A. baumannii in pets, humans, and livestock, and ESBLE in livestock and humans). Using standardized indicators (antibiotic drugsbacteria species couple) for surveillance of AMR patterns across health-care settings, countries, and host species is essential. One relevant epidemiological indicator, for both animal and human, could be E. coli AMR, particularly 3GC and carbapenems. Surveillance should be accompanied by further investigations regarding genetic support of resistance between hosts for source of contamination and dynamics of propagation between reservoirs identification (human, animal, and environment).

(iii) Spread of NDM-1-producing Enterobacteriaceae in IOC confirms needs for strengthening the early warning surveillance system of AMR emergences. The region is connected to hotspots of AMR as Asia (12.0\% of traffic) characterized by high AMR prevalence in community [e.g., ESBL in China 
(69), important antibiotic consumption (70), and emergence of new AMR profiles (e.g., NDM-1, mcr-1) (71)]. Screening of travelers, returning from at risk AMR areas, with a history of hospitalization and consumption of antibiotic drugs abroad has been recently proposed (72) and could be relevant for an early emergence detection. However, screening is costly, thus, initiating reflection regarding pooling laboratory resources is essential.

Our article is the first attempt summarizing knowledge regarding AMR in both animal and human health sectors in IOC. This review clearly points out research and surveillance gaps and constitutes a tool for future activities to lead.

\section{AUTHOR CONTRIBUTIONS}

NG performed the review, collected the data from literature, and wrote the first draft of the manuscript; EC, OB, and LFilleul

\section{REFERENCES}

1. FAO. Drivers, Dynamics and Epidemiology of Antimicrobial Resistance in Animal Production. (2016). Available from: http://www.who.int/mediacentre/ factsheets/fs194/en/

2. Laxminarayan R, Duse A, Wattal C, Zaidi AK, Wertheim HF, Sumpradit N, et al. Antibiotic resistance-the need for global solutions. Lancet Infect Dis (2013) 13:1057-98. doi:10.1016/S1473-3099(13)70318-9

3. Pagel SW, Gautier P. Use of antimicrobial agents in livestock. Rev Sci Tech (2012) 31:145-88. doi:10.20506/rst.31.1.2106

4. Wegener H. Antibiotic resistance-linking human and animal health. Improving Food Safety through a One Health Approach: Workshop Summary. (2012). 418 p. Available from: http://www.nap.edu/catalog/13423/improvingfood-safety-through-a-one-health-approach-workshop-summary

5. COI. Rapport Annual 2015. Port Saint Louis: Commission de l'Océan Indien (2015). 114 p. Available from: http://commissionoceanindien.org/ fileadmin/resources/SG/Rapport annuel 2015.pdf

6. Magiorakos AP, Srinivasan A, Carey RB, Carmeli Y, Falagas ME, Giske CG, et al. Multidrug-resistant, extensively drug-resistant and pandrugresistant bacteria: an international expert proposal for interim standard definitions for acquired resistance. Clin Microbiol Infect (2012) 18:268-81. doi:10.1111/j.1469-0691.2011.03570.x

7. von Eiff C, Becker K, Machka K, Stammer H, Peters G. Nasal carriage as a source of Staphylococcus aureus bacteremia. Study group. N Engl J Med (2001) 344:11-6. doi:10.1056/NEJM200101043440102

8. McCaig LF, McDonald LC, Mandal S, Jernigan DB. Staphylococcus aureusassociated skin and soft tissue infections in ambulatory care. Emerg Infect Dis (2006) 12:1715-23. doi:10.3201/eid1211.060190

9. Mulligan ME, Murray-Leisure KA, Ribner BS, Standiford HC, John JF, Korvick JA, et al. Methicillin-resistant Staphylococcus aureus: a consensus review of the microbiology, pathogenesis, and epidemiology with implications for prevention and management. Am J Med (1993) 94:313-28. doi:10.1016/0002-9343(93)90063-U

10. Rasamiravaka T, Rasoanandrasana S, Zafindraibe NJ, Rakoto Alson AO, Rasamindrakotroka A. Evaluation of methicillin-resistant Staphylococcus aureus nasal carriage in Malagasy patients. J Infect Dev Ctries (2013) 7:318-22. doi: $10.3855 /$ jidc. 2460

11. Rasamiravaka T, Nirinarimanana AJ, Rasamindrakotroka A. Evaluation of methicillin-resistant Staphylococcus aureus nasal carriage in Malagasy students. Afr J Clin Exp Microbiol (2016) 17:250-5. doi:10.4314/ajcem. v17i4.5

12. Randrianirina F, Soares J-L, Ratsima E, Carod J-F, Combe P, Grosjean P, et al. In vitro activities of 18 antimicrobial agents against Staphylococcus aureus isolates from the Institute Pasteur of Madagascar. Ann Clin Microbiol Antimicrob (2007) 6:5. doi:10.1186/1476-0711-6-5 revised and provided first feedback for the manuscript. All authors provided articles, have drafted, and revised the work critically for important intellectual contents and approved the final version. All authors agreed to be accountable for all aspects of the work in ensuring that questions related to the accuracy or integrity of any part of the work are appropriately investigated and resolved.

\section{ACKNOWLEDGMENTS}

The authors thank Félix Guyon Hospital for technical laboratory support.

\section{FUNDING}

This article has been funded by the Indian Ocean Health Agency and the European Regional Development Fund "Traquer les Risques Sanitaires dans l'Océan Indien avec une approche One Health."

13. Hu Q, Peng H, Rao X. Molecular events for promotion of vancomycin resistance in vancomycin intermediate Staphylococcus aureus. Front Microbiol (2016) 7:1601. doi:10.3389/fmicb.2016.01601

14. Belmonte O, Moiton MP, Drouet D, Lefort Y, Alba J, Jaffar-Bandjee MC. Particularité de l'écologie bactérienne réunionnaise: actualité au centre hospitalier Félix Guyon (CHFG). Société de pathologie infectieuse de langue française Editor. Paris, France: Réunion Interdisciplinaire de Chimiothérapie Anti-Infectieuse (2008). Available from: http://www.ricai.fr/archives

15. Randrianirina F, Vaillant L, Ramarokoto CE, Rakotoarijaona A, Andriamanarivo ML, Razafimahandry HC, et al. Antimicrobial resistance in pathogens causing nosocomial infections in surgery and intensive care units of two hospitals in Antananarivo, Madagascar. J Infect Dev Ctries (2010) 4:74-82. doi:10.3855/jidc.454

16. Issack MI, Manraj SS. Antibiotic susceptibility of bacteria isolated from hospitalised patients in Mauritius. Center for Disease Dynamics Economics and Policy Editor. 1st Global Forum on Bacterial Infections: Balancing Treatment Access and Antibiotic Resistance 2011. New Delhi, India (2011). Available from: https://f1000research.com/posters/1089854

17. Rasamiravaka T, Shaista Sheila HS, Rakotomavojaona T, Rakoto-Alson AO, Rasamindrakotroka A. Changing profile and increasing antimicrobial resistance of uropathogenic bacteria in Madagascar. Med Mal Infect (2015) 45:173-6. doi:10.1016/j.medmal.2015.03.006

18. Issack MI. Antibiotic resistance among hospitalized patients in Mauritius in 2014. Int J Infect Dis (2016) 45S:1-477. doi:10.1016/j.ijid.2016.02.250

19. Moodley A, Nightingale EC, Stegger M, Nielsen SS, Skov RL, Guardabassi L. High risk for nasal carriage of methicillin-resistant Staphylococcus aureus among Danish veterinary practitioners. Scand J Work Environ Health (2008) 34:151-7. doi:10.5271/sjweh.1219

20. Murray BE. Vancomycin-resistant enterococcal infections. N Engl J Med (2000) 342:710-21. doi:10.1056/NEJM200003093421007

21. Woodford N, Johnson AP, Morrison D, Speller DC. Current perspectives on glycopeptide resistance. Clin Microbiol Rev (1995) 8:585-615.

22. Picot S, Rakotomalala RS, Farny K, Simac C, Michault A. [Evolution of resistance to antibiotics from 1997 to 2005 in the Reunion Island]. Med Mal Infect (2010) 40:617-24. doi:10.1016/j.medmal.2010.04.001

23. van den Bogaard AE, Stobberingh EE. Epidemiology of resistance to antibiotics. Links between animals and humans. Int J Antimicrob Agents (2000) 14:327-35. doi:10.1016/S0924-8579(00)00145-X

24. Zhanel GG, DeCorby M, Adam H, Mulvey MR, McCracken M, LagacéWiens P, et al. Prevalence of antimicrobial-resistant pathogens in Canadian hospitals: results of the Canadian Ward Surveillance study (CANWARD 2008). Antimicrob Agents Chemother (2010) 54:4684-93. doi:10.1128/ AAC.00469-10

25. Ventola CL. The antibiotic resistance crisis: part 1: causes and threats. $P T$ (2015) 40:277-83. 
26. Gérardin P, Farny K, Simac C, Laurent AF, Grandbastien B, Robillard PY. [Pseudomonas aeruginosa infections in a neonatal care unit at Reunion Island]. Arch Pediatr (2006) 13:1500-6. doi:10.1016/j.arcped.2006.09.007

27. Naze F, Jouen E, Randriamahazo RT, Simac C, Laurent P, Blériot A, et al. Pseudomonas aeruginosa outbreak linked to mineral water bottles in a neonatal intensive care unit: fast typing by use of high-resolution melting analysis of a variable-number tandem-repeat locus. J Clin Microbiol (2010) 48:3146-52. doi:10.1128/JCM.00402-10

28. Jeannot K, Belmonte O, Fournier D, Robert-Nicoud R, Müller E, Plésiat P. Epidémiologie des $\beta$-lactamases à spectre élargi (BLSE) et des carbapénèmases chez Pseudomonas aeruginosa sur l’̂̀le de la Réunion. Paris: Réunion Interdisciplinaire de Chimiothérapie Anti-Infectieuse (2012).

29. Hocquet D, Colomb M, Dehecq B, Belmonte O, Courvalin P, Plésiat P, et al. Ceftazidime-hydrolysing $\beta$-lactamase OXA-145 with impaired hydrolysis of penicillins in Pseudomonas aeruginosa. JAntimicrob Chemother (2011) 66:1745-50. doi:10.1093/jac/dkr187

30. Peleg AY, Seifert H, Paterson DL. Acinetobacter baumannii: emergence of a successful pathogen. Clin Microbiol Rev (2008) 21:538-82. doi:10.1128/ CMR.00058-07

31. Andriamanantena TS, Ratsima E, Rakotonirina HC, Randrianirina F, Ramparany L, Carod JF, et al. Dissemination of multidrug resistant Acinetobacter baumannii in various hospitals of Antananarivo, Madagascar. Ann Clin Microbiol Antimicrob (2010) 9:17. doi:10.1186/1476-0711-9-17

32. Belmonte O, Drouet D, Alba J, Moiton MP, Kuli B, Lugagne-Delpon N, et al. [Evolution of Enterobacteriaceae resistance to antibiotics in Reunion Island: emergence of extended-spectrum beta-lactamases]. Pathol Biol (2010) 58:18-24. doi:10.1016/j.patbio.2009.07.021

33. Pailhoriès $\mathrm{H}$, Belmonte $\mathrm{O}$, Kempf $\mathrm{M}$, Lemarié $\mathrm{C}$, Cuziat J, Quinqueneau $\mathrm{C}$, et al. Diversity of Acinetobacter baumannii strains isolated in humans, companion animals, and the environment in Reunion Island: an exploratory study. Int J Infect Dis (2015) 37:64-9. doi:10.1016/j.ijid.2015.05.012

34. Bonnin RA, Poirel L, Benoit-Cattin T, Nordmann P. Ceftazidime-susceptible and imipenem-non-susceptible OXA-58-producing Acinetobacter baumannii from the Comoros, Archipelago. Int J Antimicrob Agents (2013) 41:297-8. doi:10.1016/j.ijantimicag.2012.11.002

35. Belmonte $\mathrm{O}$, Pailhoriès $\mathrm{H}$, Kempf $\mathrm{M}$, Gaultier MP, Lemarié $\mathrm{C}$, Ramont $\mathrm{C}$, et al. High prevalence of closely-related Acinetobacter baumannii in pets according to a multicentre study in veterinary clinics, Reunion Island. Vet Microbiol (2014) 170:446-50. doi:10.1016/j.vetmic.2014.01.042

36. Pailhoriès H, Kempf M, Belmonte O, Joly-Guillou M-L, Eveillard M. First case of OXA-24-producing Acinetobacter baumannii in cattle from Reunion Island, France. Int J Antimicrob Agents (2016) 48:763-4. doi:10.1016/j. ijantimicag.2016.09.005

37. Gootz TD, Marra A. Acinetobacter baumannii: an emerging multidrugresistant threat. Expert Rev Anti Infect Ther (2008) 6:309-25. doi:10.1586/ 14787210.6.3.309

38. Liakopoulos A, Mevius D, Ceccarelli D. A review of SHV extended-spectrum $\beta$-lactamases: neglected yet ubiquitous. Front Microbiol (2016) 7:1374. doi:10.3389/fmicb.2016.01374

39. Kliebe C, Nies BA, Meyer JF, Tolxdorff-Neutzling RM, Wiedemann B. Evolution of plasmid-coded resistance to broad-spectrum cephalosporins. Antimicrob Agents Chemother (1985) 28:302-7. doi:10.1128/ AAC.28.2.302

40. Randrianirina F, Soares JL, Carod JF, Ratsima E, Thonnier V, Combe P, et al. Antimicrobial resistance among uropathogens that cause communityacquired urinary tract infections in Antananarivo, Madagascar. J Antimicrob Chemother (2007) 59:309-12. doi:10.1093/jac/dkl466

41. Andriatahina T, Randrianirina F, Hariniana ER, Talarmin A, Raobijaona H, Buisson Y, et al. High prevalence of fecal carriage of extended-spectrum beta-lactamase-producing Escherichia coli and Klebsiella pneumoniae in a pediatric unit in Madagascar. BMC Infect Dis (2010) 10:204. doi:10.1186/1471-2334-10-204

42. Herindrainy P, Randrianirina F, Ratovoson R, Ratsima Hariniana E, Buisson Y, Genel N, et al. Rectal carriage of extended-spectrum betalactamase-producing Gram-negative bacilli in community settings in Madagascar. PLoS One (2011) 6:e22738. doi:10.1371/journal.pone.0022738

43. Chereau F, Herindrainy P, Garin B, Huynh BT, Randrianirina F, Padget M, et al. Colonization of extended-spectrum- $\beta$-lactamase- and NDM-1producing Enterobacteriaceae among pregnant women in the community in a low-income country: a potential reservoir for transmission of multiresistant Enterobacteriaceae to neonates. Antimicrob Agents Chemother (2015) 59:3652-5. doi:10.1128/AAC.00029-15

44. Micheel V, Hogan B, Rakotoarivelo RA, Rakotozandrindrainy R, Razafimanatsoa F, Razafindrabe T, et al. Identification of nasal colonization with $\beta$-lactamase-producing Enterobacteriaceae in patients, health care workers and students in Madagascar. Eur J Microbiol Immunol (2015) 5:116-25. doi:10.1556/EUJMI-D-15-00001

45. Naas T, Cuzon G, Robinson AL, Andrianirina Z, Imbert P, Ratsima E, et al. Neonatal infections with multidrug-resistant ESBL-producing E. cloacae and K. pneumoniae in neonatal units of two different hospitals in Antananarivo, Madagascar. BMC Infect Dis (2016) 16:275. doi:10.1186/ s12879-016-1580-5

46. Rakotonirina HC, Garin B, Randrianirina F, Richard V, Talarmin A, Arlet G. Molecular characterization of multidrug-resistant extended-spectrum $\beta$-lactamase-producing Enterobacteriaceae isolated in Antananarivo, Madagascar. BMC Microbiol (2013) 13:85. doi:10.1186/1471-2180-13-85

47. Coque TM, Novais A, Carattoli A, Poirel L, Pitout J, Peixe L, et al. Dissemination of clonally related Escherichia coli strains expressing extended-spectrum beta-lactamase CTX-M-15. Emerg Infect Dis (2008) 14:195-200. doi:10.3201/ eid1402.070350

48. Issack MI, Yee Kin Tet HY, Morlat P. Antimicrobial resistance among Enterobacteriaceae causing uncomplicated urinary tract infections in Mauritius: consequences of past misuse of antibiotics. J Chemother (2007) 19:222-5. doi:10.1179/joc.2007.19.2.222

49. Randrianirina F, Ratsima EH, Ramparany L, Randremanana R, Rakotonirina HC, Andriamanantena T, et al. Antimicrobial resistance of bacterial enteropathogens isolated from stools in Madagascar. BMC Infect Dis (2014) 14:104. doi:10.1186/1471-2334-14-104

50. Robin F, Beyrouthy R, Vaux S, Belmonte O, Picot S, Bonnet R. Epidemiologie des souches d’entérobactéries productrices de BLSE à la Réunion. Réunion Interdisciplinaire de Chimiothérapie Anti-Infectieuse. Paris: Réunion Interdisciplinaire de Chimiothérapie Anti-Infectieuse (2014). Available from: http://www.ricai.fr/archives

51. Belmonte O, Pailhoriès H, Kempf M, Gaultier MP, Lotteau H, Legendre P, et al. Prevalence of multiresistant Gram-negative bacteria in pets according to a cross-sectional study conducted in veterinary clinics, La Reunion Island. Federation of European Microbiological Societies. 5th Congress of European Microbiologists. Leipzig, Germany (2013).

52. Miltgen G, Cardinale E, Traversier N, Marichal A, Jaffar-Bandjee MC, Meenowa D, et al. Prévalence des entérobactéries BLSE chez les animaux délevage sur plusieurs îles de l'Océan Indien. Société de pathologie infectieuse de langue française Editor. Paris: Réunion Interdisciplinaire de Chimiothérapie Anti-Infectieuse (2014). Available from: http://www.ricai. fr/archives

53. Poirel L, Lascols C, Bernabeu S, Nordmann P. NDM-1-producing Klebsiella pneumoniae in Mauritius. Antimicrob Agents Chemother (2012) 56:598-9. doi:10.1128/AAC.05639-11

54. Cabanes F, Lemant J, Picot S, Simac C, Cousty J, Jalin L, et al. Emergence of Klebsiella pneumoniae and Salmonella metallo-beta-lactamase (NDM-1) producers on Reunion Island. J Clin Microbiol (2012) 50:3812. doi:10.1128/ JCM.01029-12

55. Miltgen G, Avril C, Benoit-Cattin T, Bonnin RA, Tamime M, Cardinale E, et al. Epidémie d'Enterobacter cloacae producteurs de carbapénèmases de type IMI-1 à Mayotte. Société de pathologie infectieuse de langue française Editor. Paris: Réunion Interdisciplinaire de Chimiothérapie Anti-Infectieuse (2016). Available from: http://www.ricai.fr/archives

56. Issack MI, Hendriksen RS, Hyytiä-Trees E, Svendsen CA, Mikoleit M. Emergence and clonal dissemination of Salmonella enterica serovar Enteritidis causing salmonellosis in Mauritius. J Infect Dev Ctries (2014) 8:454-60. doi: $10.3855 /$ jidc. 3695

57. Issack MI. Antibiotic resistance among gastrointestinal and respiratory tract bacterial pathogens in Mauritius. Int J Infect Dis (2016) 45S:1-477. doi:10.1016/j.ijid.2016.02.742

58. Henry I, Granier S, Courtillon C, Lalande F, Chemaly M, Salvat G, et al. Salmonella enterica subsp. enterica isolated from chicken carcasses and environment at slaughter in Reunion Island: prevalence, genetic characterization and antibiotic susceptibility. Trop Anim Health Prod (2013) 45:317-26. doi:10.1007/s11250-012-0221-2 
59. Petat EA, Martinet F, Lemmens P, Ghysels G, Verhaegen J, Vandepitte J. Human Salmonella and Shigella infections in Moroni, the capital of Great Comoro Island (1987-1988). Ann Soc Belg Med Trop (1990) 70:297-302.

60. Randremanana RV, Randrianirina F, Sabatier P, Rakotonirina HC, Randriamanantena A, Razanajatovo IM, et al. Campylobacter infection in a cohort of rural children in Moramanga, Madagascar. BMC Infect Dis (2014) 14:372. doi:10.1186/1471-2334-14-372

61. Humphrey T, O’Brien S, Madsen M. Campylobacters as zoonotic pathogens: a food production perspective. Int J Food Microbiol (2007) 117:237-57. doi:10.1016/j.ijfoodmicro.2007.01.006

62. Garin B, Gouali M, Wouafo M, Perchec AM, Pham MT, Ravaonindrina N, et al. Prevalence, quantification and antimicrobial resistance of Campylobacter spp. on chicken neck-skins at points of slaughter in 5 major cities located on 4 continents. Int J Food Microbiol (2012) 157:102-7. doi:10.1016/j. ijfoodmicro.2012.04.020

63. Kahsay AG, Muthupandian S. A review on Sero diversity and antimicrobial resistance patterns of Shigella species in Africa, Asia and South America, 2001-2014. BMC Res Notes (2016) 9:422. doi:10.1186/s13104016-2236-7

64. Cassel-Béraud AM, Coulanges P, Richard C, Vaslet I. Antibiotic resistance of strains of Shigella dysenteriae and flexneri isolated in Tananarive and on the east coast of Madagascar. Bull Soc Pathol Exot (1990) 83:31-6.

65. Cantón R, Akóva M, Carmeli Y, Giske CG, Glupczynski Y, Gniadkowski M, et al. Rapid evolution and spread of carbapenemases among Enterobacteriaceae in Europe. Clin Microbiol Infect (2012) 18:413-31. doi:10.1111/j. 1469-0691.2012.03821.x

66. Solet JL, Lepec R, Flachet L, Assoumani Y, Randrianarivo-Solofoniaina AE, Nundlall TR, et al. The SEGA network: epidemiological surveillance and response in the Indian Ocean. Bull Épidémiol Hebd (2014) 7:130-5.

67. The antibiotic alarm. Nature (2013) 495:141. doi:10.1038/495141a
68. Van Boeckel TP, Brower C, Gilbert M, Grenfell BT, Levin SA, Robinson TP, et al. Global trends in antimicrobial use in food animals. Proc Natl Acad Sci U S A (2015) 112:5649-54. doi:10.1073/pnas.1503141112

69. Quan J, Zhao D, Liu L, Chen Y, Zhou J, Jiang Y, et al. High prevalence of ESBLproducing Escherichia coli and Klebsiella pneumoniae in community-onset bloodstream infections in China. J Antimicrob Chemother (2017) 72:273-80. doi:10.1093/jac/dkw372

70. Van Boeckel TP, Gandra S, Ashok A, Caudron Q, Grenfell BT, Levin SA et al. Global antibiotic consumption 2000 to 2010: an analysis of national pharmaceutical sales data. Lancet Infect Dis (2014) 14:742-50. doi:10.1016/ S1473-3099(14)70780-7

71. Liu YY, Wang Y, Walsh TR, Yi LX, Zhang R, Spencer J, et al. Emergence of plasmid-mediated colistin resistance mechanism MCR-1 in animals and human beings in China: a microbiological and molecular biological study. Lancet Infect Dis (2016) 16:161-8. doi:10.1016/S1473-3099(15)00424-7

72. Armand-Lefevre L, Ruppé E, Andremont A. ESBL-producing Enterobacteriaceae in travellers: doctors beware. Lancet Infect Dis (2017) 17:8-9. doi:10.1016/S1473-3099(16)30417-0

Conflict of Interest Statement: The authors declare that the research was conducted in the absence of any commercial or financial relationships that could be construed as a potential conflict of interest.

Copyright (c) 2017 Gay, Belmonte, Collard, Halifa, Issack, Mindjae, Palmyre, Ibrahim, Rasamoelina, Flachet, Filleul and Cardinale. This is an open-access article distributed under the terms of the Creative Commons Attribution License (CC BY). The use, distribution or reproduction in other forums is permitted, provided the original author(s) or licensor are credited and that the original publication in this journal is cited, in accordance with accepted academic practice. No use, distribution or reproduction is permitted which does not comply with these terms. 